The level of psychological resilience of a student in conditions of distance learning

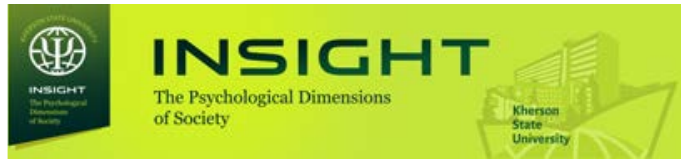

DOI: 10.32999/2663-970X/2020-3-4

Link article (Style APA): Vizniuk, I. M. \& Polishchuk, A. S. (2020). The level of psychological resilience of a student in conditions of distance learning. Insight: the psychological dimensions of society, 3, 57-68. DOI: 10.32999/2663-970X/2020-3-4

Link article (Style DSTU 8302: 2015): Vizniuk, I. M. \& Polishchuk, A. S. The level of psychological resilience of a student in conditions of distance learning. Insight: the psychological dimensions of society, 2020, 3, 57-68. DOI: 10.32999/2663-970X/2020-3-4

UDC 159.923:159.942: 371.13:37.018

\title{
The level of psychological resilience of a student in conditions of distance learning
}

\author{
Рівень психологічної стійкості студента \\ в умовах дистанційного навчання
}

Received: March 29, 2020 Accepted: May 22, 2020

Vizniuk Inessa Mykolaivna

Candidate of Psychological Sciences,

Associate Professor of the Department

of Psychology and Social Work

Vinnytsia State Pedagogical University named after Mykhailo Kotsyubynsky, Ukraine

innavisnyuk@gmail.com

ORCID 0000-0001-6538-7742

\section{Polishchuk Anna Serhiivna}

Candidate of Historical Sciences,

Senior Lecturer of the Department of World History,

Vinnytsia State Pedagogical University named after Mykhailo Kotsyubynsky, Ukraine anna_polishchukpas@ukr.net ORCID 0000-0002-0559-1087

\section{Abstract}

The purpose of the article is to determine features of psychological resilience of students during distance learning by indicators of their success. Methods: analysis, synthesis, systematization, generalization, comparison, specification and psychodiagnostic techniques. The results of the research empirically established the rela-
Візнюк Інесса Миколаївна

кандидат психологічних наук, доцент кафедри психології

та соціальної роботи

Вінницький державний педагогічний університет імені Михайла

Коцюбинського

innavisnyuk@gmail.com

ORCID 0000-0001-6538-7742

\section{Поліщук Анна Сергіївна}

кандидат історичних наук, старший викладач кафедри всесвітньої історії,

Вінницький державний педагогічний університет імені Михайла

Коцюбинського, anna_polishchukpas@ukr.net ORCID 0000-0002-0559-1087 
tionship between the level of psychological resilience formation and psychosomatic health in the research of the control group and similar indicators in the study of the experimental group. Experimental data show a significantly higher adaptability of the control group and their rational approach to life in conditions of distance learning, which is fundamentally important in preventive work to ensure the psychological health of the population of Ukraine. Emphasis is placed on activating the development of personal and value attitudes of students to psychosomatic health. A person's psychosomatic health includes: his/her environment, behavior, thinking, beliefs, identity and spirituality. Based on these features, we have created reflexive mechanisms to activate the development of personal and value attitudes of students to psychosomatic health. It is noted that its essence is: to create an emotional and communicative background to support the safe life of the individual; in the formation of appropriate habits and thinking strategies that add ingenuity in the process of overcoming stress, managing the consistency of a healthy lifestyle, adequate behavior. The conclusions show that in the educational process, the reference control (traditional form of learning) and experimental (with elements of distance learning) groups, according to the error of performance indicators do not have a significant difference, and therefore we can assume that performance indicators are approximately the same as for distance learning.

Keywords: psychological resilience of a person, author's screencasts, distance learning, information and communication technologies, mental health.

\section{Introduction}

Modern life requires a person's ability to lifelong learning, which allows him/her to remain competitive in an environment of increasing volume and rapid complication of information. This caused significant changes in the educational process and throughout the organized systematic training. Modern society places special demands on the graduate of a higher education institution, among which professionalism, activity and creativity occupy an important place. The process of improving the training of future professionals in modern education is quite complex and resulted from many factors. One of them is the problem of implementing distance learning in the process of training for future professionals, which is defined as the indirect interaction of participants, distant from each other, in a specialized space in terms of psychological, дослідження емпірично встановлено зв'язок між рівнем сформованості психологічної стійкості та психосоматичним здоров'ям у дослідженні контрольної групи та аналогічними показниками в дослідженні експериментальної групи. Експериментальні дані показують суттєво вищу адаптованість осіб контрольної групи та їх раціональний підхід до життєтворення в умовах дистанційного навчання, що грунтовно значимо в превентивній роботі щодо забезпечення психологічного здоров'я населення України. Акцентовано увагу на активації розвитку особистісно-ціннісного ставлення студентів до психосоматичного здоров'я. Зазначено, що його сутність полягає у створені емоційно-комунікативного фону підтримки безпечної життєдіяльності особистості у кожного досліджуваного; у формуванні відповідних звичок і стратегій мислення, що додають винахідливість при подоланні стресу, керуючи постійність здорового способу життя, адекватну поведінку. У висновках показано, що в умовах навчального процесу еталонна контрольна (за традиційною формою навчання) та експериментальна (3 елементами дистанційного навчання) групи, згідно похибки показників успішності, не мають суттєвої різниці, а отже, можемо вважати, що показники успішності є приблизно однаковими, стосовно дистанційного навчання.

Ключові слова: психологічна стійкість особистості авторський скрінкаст, дистанційне навчання, інформаційно-комунікаційна технологія, психологічне здоров'я.

\section{Вступ}

Сучасне життя вимагає від людини здатності до перманентного навчання, котре дозволяє їй зберігати конкурентоспроможність в умовах зростання обсягу та швидкого ускладнення інформації. Це викликало суттєві зміни у навчальному процесі та впродовж всього організованого систематичного навчання. Сучасне суспільство ставить до випускника закладу вищої освіти особливі вимоги, серед яких важливе місце посідають професіоналізм, активність і творчість. Процес удосконалення підготовки майбутніх фахівців в умовах сучасної освіти досить складний і зумовлений багатьма чинниками. Одним із них є проблема впровадження дистанційного навчання в процес підготовки професійного забезпечення майбутніх фахівців, яка визначається як опосередкована взаємодія учасників, віддалених один від одного, у спеціалізованому просторі 
The level of psychological resilience of a student in conditions of distance learning

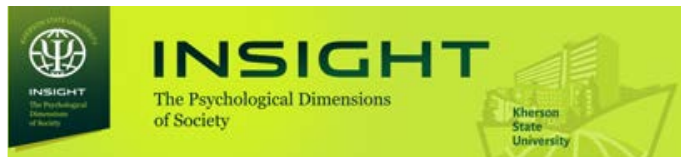

pedagogical and information and communication technologies.

Receiving new knowledge and skills used in the work of the information society, greatly expands the opportunities for self-realization of students, but also contributes to the deactivation of psychological attitudes and states that affect their actions and behavior. Unbalanced states contribute to the disharmony of the future life path of the individual. In particular, distance learning requires increased concentration, demands and often exhaustion of the individual in conditions of professional activities and learning.

In the conditions of distance learning, according to S. Maksimenko, it is important to maintain psychological balance and resilience, to adhere to life perspectives (Maksimenko, 2006). In the works of I. Arshava, it is noted that the preservation of psychological resilience of the individual is an urgent problem, the solution of which means the achievement of a person's harmonious development, maintaining optimal mental health throughout life (Arshava, 2006).

The purpose of the article is to determine the features of psychological resilience of students during distance learning by indicators of their success.

According to the set purpose the following tasks of research are defined: in the conditions of distance learning, to substantiate semantic structure of psychological resilience of the person; identify and analyze its functions in connection with the basic formations of personality.

\section{Methodology}

The methodological basis of the research were: a systematic approach to the study of psychological resilience of the individual as a system of different parametric characteristics in terms of distance learning (B. Ananiev, R. Gurevich, E. Ilyin, G. Kostyuk, S. Maksimenko); theory and practice of psychological and pedagogical research (L. Burlachuk, L. Wasserman, $\mathrm{N}$. Vodopyanova); concepts of the meaning of life and self-actualization (G. Ball, A. Maslow, D. Leontiev); psychophysiological aspect of the study of human resilience (I. Arshava, D. Kolesov, H. Linderman); psychosomatic developments of features of optimal functioning of the personality (J. Brown, I. Malkina-Pykh, N. Pezeshkian). за умовами психолого-педагогічних та інформаційно-комунікаційних технологій.

Надбання нових знань і навичок, що застосовуються у роботі в епоху інформаційного суспільства, значно розширює можливості самореалізації студентів, але й сприяє дезактивації психологічних настроїв та станів, які впливають на їх вчинки та поведінку. Неврівноважені стани сприяють дисгармонії майбутнього життєвого шляху особистості. Зокрема, дистанційне навчання вимагає посиленої зосередженості, вимогливості й, часто, виснаженості особистості в умовах виконання професійної діяльності та навчання.

В умовах дистанційного навчання, як стверджує С. Максименко, важливо зберігати психологічну рівновагу та стійкість, дотримуватися життєвих перспектив (Maksimenko, 2006). У працях I. Аршави зазначається, що збереження психологічної стійкості особистості є актуальною проблемою, розв'язання якої означає досягнення особистістю гармонійного розвитку, підтримання оптимального психічного здоров'я впродовж всього життя (Аршава, 2006).

Метою статті $\epsilon$ визначення особливостей психологічної стійкості у студентів під час дистанційного навчання за показниками їx успішності.

Визначено такі завдання дослідження: в умовах дистанційного навчання, обгрунтувати змістову структуру психологічної стійкості особистості; виявити та проаналізувати іï функції у зв'язку з базовими утвореннями особистості.

\section{Методологія}

Методологічну основу дослідження склали: системний підхід до вивчення психологічної стійкості особистості як системи різних параметричних характеристик в аспекті дистанційного навчання (Б. Ананьєв, Р. Гуревич, Є. Ільїн, Г. Костюк, С. Максименко); теорія та практика психолого-педагогічного дослідження (Л. Бурлачук, Л. Васерман, Н. Водоп'янова); концепції сенсу життя і самоактуалізації (Г. Балл, А. Маслоу, Д. Леонтьєв); психофізіологічний аспект дослідження стійкості людини (I. Аршава, Д. Колесов, Х. Ліндерман); психосоматичні розробки особливостей оптимального функціонування особистості (Дж. Браун, I. Малкіна-Пих, Н. Пезешкіан). 
The following methods were used in the research process: analysis, synthesis, systematization, generalization, comparison, concretization and psychodiagnostic methods.

\section{Participants}

Students of Vinnytsia Mykhailo Kotsyubynsky State Pedagogical University, faculties of history and psychology were involved in the experiment, on the basis of which the research was implemented. During the psychological and pedagogical experiment, a sample of experimental group (EG) was attended by 74 people, using elements of distance learning and control group (CG) in the number of 80 people who study according to the traditional use of static and natural visualization.

\section{Procedure and tools}

The following research methods were used to perform the tasks and test the hypothesis: observation (the subject of observations was the educational activities of students during on-line classes); conversation (was held with students in the process of analyzing the results of on-line surveys); content analysis as a method of studying documentation (was studied information on the results of practical work in the web service Google Classroom) and psychodiagnostic tools, which combined the following techniques: "Wiesbaden WISPF Questionnaire" by N. Pezeshkian, aimed to evaluate the characteristics and personal characteristics of ways to overcome conflicts caused by disharmony and psychosomatic health disorders; questionnaire "Adaptability" (MLO) A. Maklakov and S. Chermyanin, according to which the possibilities of active adaptation of the individual to the conditions of physical and social space at all levels of functioning of the organism and the formation of personality are highlighted; D. Leontiev's test of semanticlife orientations (SLO), according to which the system of semantic regulation of personality life is determined.

The main structural and substantive stages of the experiment are: definition of structural elements (variables, experimental hypothesis, etc.); measurement of the total sample by the nominative marker "psychosomatic health"; selection of equivalent (randomized) in accordance with the needs of the study of the reference CG (traditional form of learning) and EG (with elements of distance learning) groups; ascertaining diagnostic measurement
У процесі дослідження застосовано такі методи: аналізування, синтезування, систематизація, узагальнення, порівняння, конкретизація та психодіагностичні методики.

\section{Учасники}

До експерименту були залучені студенти Вінницького державного педагогічного університету імені Михайла Коцюбинського, історичного та психологічного факультетів, на базі яких й проводилось дослідження. У ході психолого-педагогічного експерименту за вибіркою експериментальної групи (ЕГ) взяли участь 74 особи, з використанням елементів дистанційного навчання і контрольної групи (КГ) в кількості 80 осіб, які навчаються згідно традиційного використання статичної та натуральної наочності.

\section{Процедура та інструменти}

Для виконання поставлених завдань та перевірки гіпотези були використані такі методи дослідження: спостереження (предметом спостережень була навчальна діяльність студентів під час on-line-занять); бесіда (проводилася зі студентами у процесі аналізування результатів on-line-опитування); контент-аналізування як метод вивчення документації (вивчалися відомості за результатами практичних робіт у веб-сервісі Google Classroom) та психодіагностичний інструментарій, який поєднав такі методики: "Вісбаденський опитувальник WIPPF” Н. Пезешкіана, призначений для оцінки характерологічних і особистісних особливостей щодо способів подолання конфліктів, зумовлених дисгармонією і розладом психосоматичного здоров'я; опитувальник "Адаптивність" (МЛО) А. Маклакова і С. Чермяніна, згідно якого висвітлено можливості активного пристосування індивіда до умов фізичного і соціального простору на всіх рівнях функціонування організму та формування особистості; тест смисложиттєвих орієнтацій (СЖО) Д. Леонтьєва, за яким визначено систему смислової регуляції життєдіяльності особистості.

Основні структурно-змістовні етапи експерименту такі: визначення структурних елементів (змінних, експериментальної гіпотези тощо); вимір загальної вибірки за номінативним маркером “психосоматичне здоров'я"; відбір еквівалентних (рандомізованих) відповідно до потреб дослідження еталонної КГ 
in CG and EG by a number of psychodiagnostic techniques that determine the main parameters of measuring the psychological resilience of the individual for successful distance learning and their relationship with other parameters of the research; qualitative and quantitative analysis of results to establish statistically significant differences between CG and EG; contrast and comparison of results in groups with different characteristics; systematization and generalization of the results of theoretical and empirical research.

\section{Statistical analysis}

In the process of statistical processing of psychodiagnostic data, the method of checking the probability of sample differences in the division of traits was used by means of Pearson's criterion $\chi 2$, Spearman's rank correlation coefficient $-r_{s^{\prime}}$ which allows to evaluate the strength and direction of consistency of changes between two traits, and Student's criterion related to checking the equality of mean values in two samples. Thus, the experimental plan was used, statistical processing methods, its implementation and interpretation of the results ensured internal and external validity.

\section{Results}

The distance course created by us is a combination of structured theoretical material and a set of practical works. In the process of giving classes, the teacher used the created distance course, which greatly simplified the explanation of new educational material and helped to involve students in activities. At the end of the lesson, they had the opportunity to complete a web-quest on this topic. Students were also interested in the presented study material, as it was presented in new ways, which provided better concentration and motivation, and therefore more effective mastery. The required software was adapted using Macromedia Flash.

Determining the above features of distance learning (DL) contributed to the separation of psychological and temporal indicators of psychosomatic disorders for the further system of medical and psychological rehabilitation of future professionals, taking into account the differentiation of mechanisms of their occurrence. Then the theoretical material is presented in the form of a lecture course created using Macromedia Flash. At each lesson, the author's screencasts and mental maps were demonstrated by means of cloud technologies. These tools structure the theoretical (за традиційною формою навчання) та ЕГ (з елементами дистанційного навчання) груп; констатувальний діагностичний зріз (вимір) в КГ та ЕГ низкою психодіагностичних методик, які визначають основні параметри виміру психологічної стійкості особистості щодо успішного дистанційного навчання та їхні зв'язки $з$ іншими параметрами дослідження; якісний та кількісний аналіз результатів для встановлення статистично значущих відмінностей КГ та ЕГ; зіставлення та порівняння результатів у групах з різними характеристиками; систематизація та узагальнення результатів теоретико-емпіричного дослідження.

Статистичне аналізування

У процесі статистичної обробки даних психодіагностичних досліджень використано методику перевірки вірогідності різниць вибірок у розподілі ознак за допомогою критерію х2 Пірсона, коефіцієнт рангової кореляції Спірмена $-\mathrm{r}_{s^{\prime}}$ що дозволяє оцінити силу та напрям узгодженості змін між двома ознаками, та t критерій Ст'юдента, що пов'язаний із перевіркою рівності середніх значень у двох вибірках. Отже, використаний експериментальний план, методи статистичної обробки, іï проведення та інтерпретація результатів забезпечили внутрішню та зовнішню валідність.

\section{Результати}

Створений нами дистанційний курс - це поєднання структурованого теоретичного матеріалу та комплексу практичних робіт. У процесі проведення занять викладач використовував створений дистанційний курс, що значно полегшувало пояснення нового навчального матеріалу та сприяло залученню до активної діяльності студентів. Після закінчення заняття вони мали змогу виконати веб-квест із даної теми. Студенти також зацікавились поданим навчальним матеріалом, оскільки він подавався новими для них засобами, що сприяло кращій концентрації уваги та мотивації, а отже, більш ефективному його опануванню. Комплекс необхідного програмного забезпечення було адаптовано за допомогою програми "Macromedia Flash".

Визначенні вищезазначені особливості дистанційного навчання (ДН) сприяли виокремленню психолого-часових індикаторів наявності психосоматичних порушень для подальшої системи медико-психологічної реабілітації майбутніх фахівців, шляхом врахування диференціації механізмів їх виникнення. Надалі теоретичний матеріал представлено у вигляді 
components of the current topic of study and show the main stages of creating a typical animation.

Thus, the effectiveness of the open source DL platform has been practically proved under the conditions of qualified training of future specialists.

According to Student's criterion $\left(\mathrm{SM}_{1}=\sqrt{\mathrm{SS}} \mathrm{S}_{1} /\right.$ $\mathrm{N}_{1}\left(\mathrm{~N}_{1}-1\right) ; \mathrm{Sm}_{1}=0,191 ; \mathrm{Sm}_{2}=\sqrt{\mathrm{SS}_{2}} / \mathrm{N}_{2}\left(\mathrm{~N}_{2}-1\right)$; $\left.\mathrm{SM}_{2}=0,194\right)$ it is established that the error is not significant and the success rates of CG and EG approximately the same, the identity of which allows you to focus on students of the CG. Further, the effectiveness of the use of DL technologies in the educational process of freelance students was determined. Thus, the main task of distance learning was the development of intellectual abilities through the open and free use of educational resources and programs available online.

The success of the use of interactive posters and design technologies according to the definition of Student's criterion on the topic of "Computer Animation" is revealed in EG by computer input of values, while in CG individuals - in writing (on prepared forms). According to calculations $\mathrm{SM}_{1}=\sqrt{\mathrm{SS}_{1}} / \mathrm{N}_{1}\left(\mathrm{~N}_{1}-1\right) ; \mathrm{Sm}_{1}=0,19 ; \mathrm{Sm}_{2}=\sqrt{\mathrm{SS}_{2}} /$ $\mathrm{N}_{2}\left(\mathrm{~N}_{2}-1\right) ; \mathrm{Sm}_{2}=0,194$ and $\mathrm{Sm}_{1} ; \Delta_{1}=0,293 \pm 0,37$; $\Delta_{2}=\mathrm{M}_{2} \pm 1.96 * \mathrm{SM}_{2} ; \Delta_{2}=0,289 \pm 0,38$ we observe a more significant error, which indicates the effectiveness of the use of DL during the educational process in institutions of high education.

Thus, the control and experimental samples for the implementation of DL in the educational process do not differ significantly. Distance education is organized on the following principles: accessibility of education (for people with disabilities, increasing the audience of applicants); individual orientation of education, providing comfortable conditions for students and teachers, consideration of individual psychological features of cognitive processes, individual pace of learning; improvement of information culture, etc.

Subsequent results of our study showed a difference between the groups. These differences were in the substantiation of psychosomatic factors underlying the emergence of a tendency to pessimistic moods of students in the EG. At the ascertaining stage of the empirical research, a psychodiagnostic examination of CG and EG students was also performed according to a set of methods.

Carrying out a qualitative analysis of the results of the ascertaining stage of the study revealed the socio-psychological features of the psychological лекційного курсу, створеного за допомогою програми "Macromedia Flash".

На кожному занятті демонструвалося, засобами хмарних технологій, авторські скрінкасти та ментальні карти. У цих засобах структуровано теоретичні складові актуальної теми вивчення і показано основні етапи створення типової анімації.

Отож, практично було доведено ефективність застосування платформи ДН з відкритим кодом за умов кваліфікованої підготовки майбутніх фахівців.

За критерієм Стьюдента $\left(\mathrm{Sm}_{1}=\sqrt{\mathrm{SS}_{1}} /\right.$

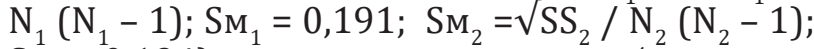
$\left.\mathrm{Sm}_{2}=0,194\right)$ встановлено, що похибка показників не є суттєвою і показники успішності КГ та ЕГ приблизно однакові, ідентичність яких дозволяє орієнтуватися на показники КГ осіб. Надалі було визначено ефективність використання технологій ДН у навчальному процесі студентів 3ВО. Головним завданням дистанційного навчання був розвиток інтелектуальних здібностей людини за допомогою відкритого та вільного використання освітніх ресурсів і програм, доступних в он-лайн мережі.

Успішність застосування інтерактивного плакату та проектних технологій за визначенням критерію Стьюдента з теми “Комп”ютерна анімація” розкрито у ЕГ шляхом комп'ютерного введення значень тоді, як у КГ осіб - письмово (на заготовлених бланках). За розрахунками $\mathrm{Sm}_{1}=\sqrt{\mathrm{SS}_{1}} / \mathrm{N}_{1}\left(\mathrm{~N}_{1}-1\right) ; \mathrm{Sm}_{1}=0,19 ; \mathrm{Sm}_{2}=\sqrt{\mathrm{SS}_{2}} /$ $\mathrm{N}_{2}\left(\mathrm{~N}_{2}-1\right) ; \mathrm{Sm}_{2}=0,194$ та $\mathrm{Sm}_{1} ; \Delta_{1}=0,293 \pm 0,37$; $\Delta_{2}=\mathrm{M}_{2} \pm 1.96 * \mathrm{SM}_{2} ; \Delta_{2}=0,289 \pm 0,38$ спостерігаємо більш значущу похибку, що свідчить про ефективність застосування ДН під час навчального процесу в ЗВО.

Таким чином, контрольна та експериментальні вибірки щодо впровадження ДН в освітній процес не мають істотних відмінностей. Дистанційна освіта організована за такими принципами: доступність навчання (для людей з фізичними обмеженнями, збільшення аудиторії здобувачів); індивідуальна спрямованість навчання, забезпечення комфортних умов для студентів і викладачів, зважування на індивідуальні психологічні особливості когнітивних процесів, індивідуальний темп навчання; вдосконалення інформаційної культури тощо.

Подальші результати нашого дослідження показали диференційну відмінність між групами. Ці відмінності полягали в обгрунтуванні психосоматичних чинників, що лежать в основі 
The level of psychological resilience of a student in conditions of distance learning

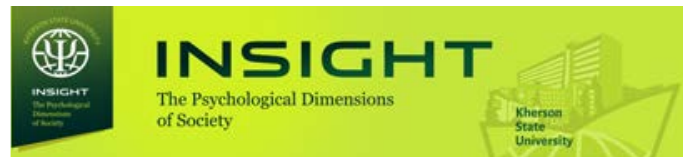

resilience of the individual during distance learning. It should be noted that EG respondents showed a tendency to pessimism and the presence ofpsychosomatosis(disordersofthegastrointestinal tract (GIT), skin covering (SC) and cardiovascular system (CVS)).

1. According to the Wiesbaden WIPPF questionnaire (N. Pezeshkian), which is designed to evaluate the characterological and personal characteristics and ways of processing conflicts, a number of differences were identified due to disharmony and psychosomatic health disorders. It was found that the majority of respondents, both CG and EG, are dominated by normative (within 5-10 points) indicators of features - from $61.11 \%$ ("fairness") to $91.67 \%$ ("sociability") of the students of CG, from $65.79 \%$ ("love") to $92.11 \%$ ("model / they") of the EG students. The following differences between CG and EG were statistically significant, exceeding one standard deviation $(\sigma)$ : the average values of the scales "fairness", "honesty", "politeness", "obligation", "thrift", "fidelity" are higher in EG, the scales "trust", "hope", "sexuality", "body / feeling", "model / grand-we" are higher in KG.

Significant gender differences were found in the sample data: on eight scales (accuracy, neatness, thrift, obedience, patience, hope, trust, body / feeling), the average values of women exceeded one standard deviation $(\sigma)$ for men. The research found a general tendency of the sample to reduce such social norms as "neatness" and "thrift" (especially for men) and "justice". Statistical data processing shows high communication rates and significant direct intercorrelations between feelings of fairness, trust and reliability ( $p \leq 0.01)$. Since the feeling of justice or injustice is formed by human experience, we can conclude that there is a basic conflict in this area, which for men tends to transform in the direction of expanding the contact sphere, and for women - to its limitations.

In general, the analysis of the sample data revealed that the average indicator of actual abilities of the second order (cognition) is lower than the indicator of primary abilities (acceptance and love), but only in CG this difference is statistically significant $(t=2.73 ; p \leq 0.01)$.

A significant part of the EG sample was in the zone of high rates for this type of reaction as "fantasy" and partly - "relationships". The predominant reactions of the respondents to the conflicts were as follows: the tendency of mental passivity during the activity; reliance on imagination, fantasy and intuition, as well as the expansion of contacts and the sphere of social support, the latter of which turned out зародження схильності до песимістичних настроїв у ЕГ осіб. На констатувальному етапі емпіричного дослідження також проводилось психодіагностичне обстеження осіб КГ та ЕГ за комплексом методик.

Проведення якісного аналізування результатів констатувального етапу дослідження дозволило виявити соціально-психологічні особливості психологічної стійкості особистості під час дистанційного навчання. Зазначимо, що респонденти ЕГ проявили схильність до песимізму та наявність психосоматозів (порушення шлунково-кишкового тракту (ШКТ), шкірних покривів (ШП) і серцево-судинної системи (ССС)).

1. За Вісбаденським опитувальником WIPPF (Н. Пезешкіана), який призначений для оцінки характерологічних і особистісних особливостей та способів переробки конфліктів, було визначено низку відмінностей, зумовлених дисгармонією і розладом психосоматичного здоров'я. Встановлено, що у більшості респондентів, як КГ, так і ЕГ, переважають нормативні (у межах 5-10 балів) показники особливостей - від 61,11\% (“справедливість") до 91,67\% ("товариськість”) досліджуваних КГ, від 65,79 \% (“любов”) до 92,11 \% ("модель/вони") досліджуваних ЕГ. Статистично достовірними, 3 перевищенням одного стандартного відхилення $(\sigma)$ виявились такі відмінності між КГ та ЕГ: середні значення шкал “справедливість”, “чесність”, “ввічливість”, “обов'язковість”, “бережливість”, “вірність” вищі у ЕГ, а за шкалами “довіра”, “надія”, "сексуальність”, “тіло/відчуття”, “модель / пра-ми” у КГ.

Виявлено суттєві ґендерні відмінності даних вибірки: за вісьмома шкалами (акуратність, охайність, бережливість, слухняність, терпіння, надія, довіра, тіло/відчуття) середні показники жінок перевищили одне стандартне відхилення $(\sigma)$ стосовно чоловіків. У ході дослідження було виявлено загальну тенденцію вибірки до зниження таких соціальних норм, як “охайність" i "бережливість" (особливо для чоловіків), та “справедливість”. Статистична обробка даних свідчить про високі показники зв'язку та значущі прямі інтеркореляційні залежності між почуттями справедливості, довіри та надійності ( $\mathrm{p} \leq 0,01)$. Оскільки почуття справедливості чи несправедливості формується досвідом людини, то можна зробити висновок про існування у цій сфері базового конфлікту, який у чоловіків має тенденцію трансформуватись у напрямку розширення контактної сфери, а у жінок - до їі обмежень.

Загалом аналізування даних вибірки виявило, що усереднений показник актуальних зді- 
to be more typical of the sample of respondents with a tendency to pessimism and low stress resistance. When a problem arises the identified style of respondents' orientation to imagination and its development involve the creation of various conjectures, beliefs and mystical judgments, which reduce the criticality of respondents in perceiving the real situation.

Note that the participants of the EG have such critical parameters as untidiness $(47,37 \%)$, sloppiness $(57,89 \%)$, low diligence $(50,00 \%)$, disobedience $(47,37 \%)$, infidelity, 37,00\%), low patience $(47,37 \%)$, low sexuality $(68,42 \%)$, low trust $(68,42 \%)$, hope $(57,89 \%)$ and love $(57,89 \%)$. This list objectively indicates an intrapersonal conflict caused by aggression, fear, imitation, which has signs of psychosomatic disorders in the mental sphere, in the cardiovascular system, in the gastroepidermal zone, on the skin, and so on.

Adequate self-esteem and positive selfperception stimulates the personality to success, to the formation of psychological resilience. Flexible structure of basic personal formations, harmonious functional-dynamic interrelation of primary and secondary actual abilities, transcultural (dialogical) way of thinking, constructive social and psychological interaction, ability to find positive meanings of life, possession of various forms and models of conflict resolution are potential preservation and restoration of psychosomatic health.

2. Methods for evaluation the level of development of adaptive abilities of the individual (MLO) by A. G. Maklakov and S. V. Chermyanin highlights the possibilities of active adaptation of the individual to the conditions of physical and social space at all levels of functioning of the organism and the formation of personality. Significant intergroup differences were recorded both in terms of the general indicator "personal adaptation potential" $(\mathrm{t}=2,129$, $\mathrm{p} \leq$ 0.05) and in terms of its structural and functional characteristics. The leading factor in the adaptive potential of the control sample is the component "behavioral regulation" (7.1), and of the experimental one is - "moral and ethical norms" (5.8). The received data indicate negative correlations of vitality of students in the EG with the search for value-semantic orientations, social support, readiness for change, as well as the lack of adequate behavioral regulation, self-control and positive reassessment of the situation. It is бностей другого порядку (пізнання) нижчий від показника первинних здібностей (прийняття та любові), проте лише у КГ ця відмінність статистично значуща $(\mathrm{t}=2,73 ; \mathrm{p} \leq 0,01)$.

Значна частина вибірки ЕГ знаходилася в зоні високих показників за таким типом реакції, як “фантазія:" та частково - "стосунки”. Переважними реакціями респондентів на конфлікти виявилися такі: тенденція ментальної пасивності під час діяльності; опора на уяву, фантазії та інтуїцію, а також розширення контактів та сфери соціальної підтримки, остання з яких виявилася більш притаманною вибірці респондентів зі схильністю до песимізму й низькою стресостійкістю. Виявлений усталений стиль орієнтованості респондентів на фантазію та розвиток уяви передбачає створення, при виникненні проблеми, різних домислів, вірувань та містичних суджень, що зменшує критичність респондентів у сприйманні дійсної ситуації.

Зауважимо, що в учасників ЕГ критичний характер показників мають такі параметри, як неакуратність (47,37 \%), неохайність (57,89 \%), низька працьовитість (50,00\%), неслухняність (47,37\%), невірність (47,37 \%), низьке терпіння (47,37 \%), низька сексуальність (68,42 \%), низькі довіра (68,42 \%), надія $(57,89 \%)$ та любов $(57,89 \%)$. Даний перелік об'єктивно вказує на внутрішньоособистісний конфлікт, породжений агресією, страхом, наслідуванням, що має ознаки психосоматичних розладів у психічній сфері, у серцево-судинній системі, в гастроепідермальній зоні, на шкірі тощо.

Адекватна самооцінка та позитивне самосприйняття стимулює особистість до успіху, до формування психологічної стійкості. Гнучка структура базових особистісних утворень, гармонійний функціонально-динамічний взаємозв'язок первинних та вторинних актуальних здібностей, транскультурний (діалогічний) спосіб мислення, конструктивна соціально-психологічна взаємодія, здатність знаходити позитивні смисли життєдіяльності, володіння різними формами та моделями розв'язання конфліктів становлять потенціал для збереження та відновлення психосоматичного здоров'я.

2. Методика для оцінки рівня розвитку адаптаційних здібностей особистості (МЛО) А. Г. Маклакова та С. В. Чермяніна висвітлює можливості активного пристосування індивіда до умов фізичного і соціального простору на всіх рівнях функціонування організму та формування особистості. Зафіксовано суттєві міжгрупові відмінності як за загальним показником «особистісний потенціал адаптації» $(\mathrm{t}=2,129$, 
The level of psychological resilience of a student in conditions of distance learning

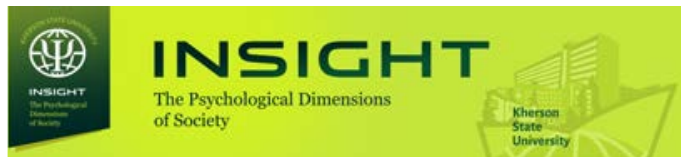

established that the high level of psychological resilience of CG students is provided by regulation of behavior, high self-esteem, and adequate perception of reality, communicative abilities, acceptance and reflective attitude to moral norms of society.

3. According to test of semantic-life orientations (SLO) of D. Leontiev, who determines the system of semantic regulation of personality, it was found by Student's criterion that the average values of the control sample are significantly higher than the average values of the experimental sample: "goals in life" $(\mathrm{t}=2.21 ; \mathrm{p} \leq 0.05)$, "saturation of life" ( $t=3.62 ; p \leq 0.001)$, "satisfaction with selfrealization" $(t=3.14 ; p \leq 0.005)$, "locus of control self" ( $t=2.38 ; p \leq 0.05)$ and "locus of control - life" $(\mathrm{t}=2.17 ; \mathrm{p} \leq 0.05)$.

The results of EG students show a focus on the past (50,00\%); pessimism, low emotional saturation of life $(78,95 \%)$; dissatisfaction with self-realization $(71,05 \%)$; disbelief in one's own strength to control the events of one's own life $(52,63 \%)$; fatalism, confidence in the illusory freedom of choice and unpredictability of the future $(50,00 \%)$ and immersed in on-line remote space. In general, the general indicator of "meaningfulness of life" in EG is below the norm, and for women it exceeds the standard deviation. So, as you can see, EG students tend to pessimism.

CG students generally received high scores on all measured parameters: according to the scale "goals in life" $(63,89 \%)$, they have clear plans for the future, which give life meaningfulness and time perspective, purposeful and responsible for life plans; on the scale of "saturation of life" $(72,22 \%)$ perceive the process of their lives as interesting, emotionally rich and full of meaning; according to the scale "satisfaction with selfrealization" $(75,00 \%)$ they are satisfied with the effectiveness of life; on the scale of "locus of control - self" $(66,67 \%)$ consider themselves a strong person who has enough freedom of choice for life; on the scale "locus of control life" $(61,11 \%)$ they are confident in the ability to freely make and implement their own decisions. The general indicator of "meaningfulness of life" of CG testifies to integration, organization of semantic structures that provides regulation of integral vital activity of the student, his/her psychological resilience.

In general, empirical research has revealed (Table 1) an indirect correlation between psychological resilience and students with a tendency to pessimism. $\mathrm{p} \leq 0,05)$, так і за його структурно-функціональними характеристиками. Провідним чинником адаптаційного потенціалу контрольної вибірки є складова «поведінкова регуляція» $(7,1$ стенів), а експериментальної - "морально-етична нормативність” (5,8 стенів). Отримані дані свідчать про негативні взаємозв'язки життєстійкості в ЕГ осіб з пошуком ціннісно-смислових орієнтацій, соціальної підтримки, готовності до змін, а також про відсутність адекватного поведінкового регулювання, самоконтролю і позитивної переоцінки ситуації. Встановлено, що високий рівень психологічної стійкості осіб КГ забезпечується регуляцією поведінки, високою самооцінкою, адекватним сприйняттям дійсності, комунікативними здібностями, прийняттям та рефлексивним ставленням до моральних норм суспільства.

3. За тестом смисложиттєвих орієнтацій (СЖО) Д.О. Леонтьєва, який визначає систему смислової регуляції життєдіяльності особистості, встановлено за критерієм Ст'юдента, що середні значення контрольної вибірки значущо вищі за середні значення експериментальної вибірки: "цілі в житті" ( $\mathrm{t}=2,21 ; \mathrm{p} \leq 0,05)$, "насиченість життя" ( $\mathrm{t}=3,62 ; \mathrm{p} \leq 0,001)$, “задоволеність самореалізацією” ( $\mathrm{t}=3,14 ; \mathrm{p} \leq 0,005)$, “локус контролю-Я" $(\mathrm{t}=2,38 ; \mathrm{p} \leq 0,05)$ та "локус контролю - життя" (t=2,17; $\mathrm{p} \leq 0,05)$.

Результати ЕГ досліджуваних показують орієнтацію на минуле (50,00 \%); песимістичність, низьку емоційну насиченість життя (78,95 \%); незадоволеність від самореалізації (71,05 \%); невіру у власні сили щодо контролю подій власного життя (52,63\%); фаталізм, упевненість в ілюзорності свободи вибору та непередбачуваності майбутнього (50,00 \%) й занурені в on-line дистанційний простір. Загальний показник “осмисленість життя" у ЕГ нижче нормативного, а в жінок виходить за межі стандартного відхилення. Отже, як видно, особи ЕГ проявляють схильність до песимізму.

Представники КГ отримали загалом високі бали за всіма вимірюваними параметрами: згідно зі шкалою "цілі в житті" (63,89 \%) вони мають чіткі задуми на майбутнє, які надають життю осмисленість та часову перспективу, цілеспрямовані та відповідальні щодо життєвих планів; за шкалою "насиченість життя" $(72,22 \%)$ сприймають процес свого життя як цікавий, емоційно насичений та наповнений змістом; згідно зі шкалою "задоволеність самореалізацією" (75,00\%) задоволені результативністю життя; за шкалою "локус контролю-Я" (66,67 \%) вважають себе сильною особистістю, 
Table 1. Relationship between indicators of psychological resilience (PR) and somatic disorders Таблиця 1. Взаємозв'язок між показниками психологічної стійкості (ПС) та соматичними порушеннями

\begin{tabular}{|c|c|c|c|}
\hline & $\begin{array}{c}\text { GIT } \\
\text { ШКТ }\end{array}$ & $\begin{array}{c}\text { CVS } \\
\text { CC }\end{array}$ & $\begin{array}{c}\text { SC } \\
\text { ШП }\end{array}$ \\
\hline $\begin{array}{c}\text { High indicators PR } \\
\text { Високі показники ПС }\end{array}$ & 0,027 & 0,017 & 0,033 \\
\hline $\begin{array}{c}\text { Low indicators PR } \\
\text { Низькі показники ПС }\end{array}$ & $0,227^{* *}$ & $0,257^{* *}$ & $0,215^{* *}$ \\
\hline
\end{tabular}

Note: ${ }^{* *}$ - the correlation is significant at the level of $\mathrm{p} \leq 0.01$. Примітка: ${ }^{* *}$ - кореляція $€$ значущою на рівні $\mathrm{p} \leq 0,01$.

It was found that the average indicators of psychological resilience of women are significantly higher than men $(11.13 \pm 0.32$ and $9.07 \pm 1.02$, respectively).

Analysis of the received data by Pearson's criterion $\chi^{2}$ shows the presence of significant differences $\left(\chi^{2}=16.87, \mathrm{p} \leq 0.01\right)$ of the average indicators of psychological resilience of CG and EG.

Thus, with the help of the comparison strategy it was stated that the reference control (psychosomatically healthy individuals) and experimental (individuals with a tendency to pessimism) groups have significantly different meanings and distribution of traits with a tendency to pessimism. The established qualitative and quantitative differences became the basis of the formative strategy, the main task of which was to bring the indicators of EG students to the indicators of the students of the CG-reference, i.e. the restoration of psychosomatic health.

\section{Discussion}

Distance learning is widely used in many countries around the world, and their DL models have significant features and are formed taking into account the economic, political and sociocultural patterns of a country and socio-economic opportunities of each institution (Ymanets, 2016).

Bykov V. and Kademiya M. claim that in recent decades DL is one of the most important components of the system of vocational education in the world, and over the past decade is an element of education in our country. On the one hand, this significance is due to the rapid development of information and communication technologies (ICT) while, on the other hand, the political beliefs of the governments of these countries in the educational space, in particular, яка має достатньо свободи вибору для життєтворчості; за шкалою "локус контролю - життя" $(61,11 \%)$ впевнені у можливості вільно приймати та втілювати власні рішення. Загальний показник "осмисленість життя" КГ свідчить про інтегрованість, організованість смислових структур, що забезпечує регуляцію цілісної життєдіяльності суб'єкта, його психологічну стійкість.

Загалом, емпіричне дослідження виявило (табл. 1) непрямий кореляційний взаємозв'язок психологічної стійкості та досліджуваних зі схильністю до песимізму.

Встановлено, що середні показники психологічної стійкості жінок значущо вищі, ніж у чоловіків $(11,13 \pm 0,32$ і 9,07 $\pm 1,02$ відповідно).

Аналізування отриманих даних за критерієм $\chi^{2}$ Пірсона засвідчує наявність достовірних різниць $\left(\chi^{2}=16,87, \mathrm{p} \leq 0,01\right)$ середніх показників психологічної стійкості КГ та ЕГ.

Таким чином, за допомогою стратегії зіставлення констатовано, що еталонна контрольна (психосоматично здорові особи) та експериментальна (особи зі схильністю до песимізму) групи мають суттєво різні значення та розподіл ознак схильністю до песимізму. Встановлені якісні та кількісні відмінності стали основою формувальної стратегії, основним завданням якої було наближення показників осіб ЕГ до показників учасників КГ-еталонної, тобто відновлення психосоматичного здоров'я.

\section{Дискусія}

Дистанційне навчання широко використовується у багатьох країнах світу, а їхні моделі ДН мають суттєві особливості та формуються з урахуванням економічних, політичних і соціокультурних закономірностей тієї чи іншої країни й соціально-економічних можливостей кожного конкретного навчального закладу (Ymanets, 2016).

Биков В. та Кадемія М. стверджують, що в останні десятиріччя ДН $є$ одним із найважливіших складових системи професійної освіти країн світу, а за минуле десятиріччя й елементом освіти нашої країни. 3 одного боку, така значимість породжена бурхливим розвитком інформаційно-комунікаційних технологій (ІКТ), тоді як з іншого, політичними переконаннями урядів цих країн в освітньому просторі, зокрема, прагненням зробити їх максимально доступними широким верствам населення (Биков, 2010; Кадемія, 2016).

У нашій країні відбуваються суттєві зміни 
the desire to make them accessible to the general public (Bykov, 2010; Kademiia, 2016).

Significant changes in the national education policy are taking place in our country. The Ukrainian school of the XXI century is the result of huge changes that have taken place in the system of national education in recent years. In this sense, the formation is not just part of the social life of society, but its vanguard: hardly any other subsystem of it can to the same extent confirm the fact of its progressive development with such an abundance of innovations and experiments.

Accordingly, it is the presence of such rapid changes in the system of science that encourages the development of psychosomatic dysfunctions of the human body and sharply reduces the level of resistance of its system. Psychological resilience is defined by us as an integral polysystemic quality of personality, outlined by the content and relationships of such structural components as: emotional, represented by emotional arousal and personal anxiety; somatic, represented by the evaluation and determination of the requirements of the situation for the optimal functioning of the organism, the forecast of its possible change and decision-making on methods of action; and the typological property of the nervous system, represented by its strength.

In the structural-hierarchical organization of psychological resilience of the personality the ability to self-development, self-actualization, formation of own individuality is important. Psychological resilience of the personality can be considered as a complex quality of the personality, synthesis of separate qualities and abilities. The components of psychological resilience include: the ability to personal growth with timely and adequate resolution of internal personal conflicts (value, motivation, and role); relative (not absolute) resilience of emotional tone and positive mood; developed volitional regulation (Vizniuk, 2017).

In view of the above, there is a need to improve the network of training, retraining, advanced training of specialists in this field in continuing education, the content of which should meet the industry standard of higher education, which will contribute to better adaptation and success of students in innovation through ICT. The content of such education should be in line with the National Qualifications Framework and the European Professional Education Portfolio. The development of programs for the study of preparatory disciplines should take place in accordance with the modern у національній політиці освіти. Українська школа XXI століття - це результат величезних змін, що відбулися у системі вітчизняної освіти за останні роки. У цьому сенсі утворення не просто частини соціального життя суспільства, а ії̈ авангард: навряд чи якась інша їі підсистема у тій самій мірі може підтвердити факт свого поступального розвитку таким достатком нововведень і експериментів.

Відповідно, що саме наявність таких швидких змін у системі науки й спонукає до розвитку психосоматичних дисфункцій організму людини та різко знижує рівень резистентності її системи. Психологічна стійкість визначається нами, як інтегральна полісистемна якість особистості, окреслена змістом і взаємозв'язками таких структурних компонентів, як: емоційний, представлений емоційним збудженням і особистісною тривожністю; соматичний, представлений оцінкою і визначенням вимог ситуації щодо оптимального функціонування організму, прогнозом її можливої зміни і прийняттям рішень про способи дій; і типологічною властивістю нервової системи, представленою її силою.

У структурно-ієрархічній організації психологічної стійкості особистості важливою $\epsilon$ здатність до саморозвитку, самоактуалізації, формування власної індивідуальності. Психологічну стійкість особистості можна розглядати, як складну якість особистості, синтез окремих якостей і здібностей. До складових психологічної стійкості необхідно віднести: здатність до особистісного зростання зі своєчасним і адекватним вирішенням внутрішньо особистісних конфліктів (ціннісних, мотиваційних, рольових); відносну (не абсолютну) стабільність емоційного тону і позитивного настрою; розвинену вольову регуляцію (Візнюк, 2017).

3 огляду на зазначене, виникає потреба вдосконалення мережі підготовки, перепідготовки, підвищення кваліфікації спеціалістів даного профілю в умовах неперервної освіти, зміст якої має відповідати галузевому стандарту вищої освіти, що сприятиме кращій адаптації і успішності студентів щодо нововведень шляхом ІКТ. Зміст такої освіти має відповідати Національній рамці кваліфікацій і Європейському портфоліо з підготовки спеціаліста у системі професійної освіти. Розробка програм вивчення підготовчих дисциплін має відбуватися відповідно до сучасних вимог Ради Європи і методик інтенсивного вдосконалення професійного забезпечення з метою 
requirements of the Council of Europe and methods of intensive improvement of professional support in order to provide graduates with free knowledge. At the same time, students need to be introduced to the international qualifications framework for the perception of their self-development.

\section{Conclusions}

Thus, in accordance with the set purpose, in the conditions of distance learning, the peculiarities of psychological resilience of students are substantiated and its functions in connection with the basic formations of personality are analyzed. It was stated that student achievement as a basic category of research doesn'tdiffer significantly between CG and EG, while psychosomatic health disorders observed in the latter group of individuals are the result of the development of such personal formations as a tendency to pessimism and low stress resistance. It was determined that there is a relationship between resilience and psychosomatic health $\left(r_{x y}=0,359, p \leq 0,01\right)$ and therefore its level in EG students is much lower than in CG, which does not affect their success in the conditions of DL. There is the similarity in the indicators of success between the studied groups, which indicates an increase in the possibility of optimal functioning of the human body in the use of ICT.

It has been shown that the psychological resilience of a person, his/her balance andadaptation duringdistancelearning,contribute to such personal formations as: purposefulness, cheerfulness, energy, perseverance, patience, enthusiasm, courage, tolerance, security.

\section{References}

Arshava, I. F. (2006). Emotional resilience of a person and its diagnostics: a monograph. Donetsk: DNU.

Bykov, V. Yu. (2010). Means of information and communication technologies of the single informationspaceofthe educationsystemofUkraine: monograph. Kyiv: Pedahohichna dumka.

Kademiya, M. Yu. (2016). Vocational education in the information society: a monograph. Vinnytsia: Nilan-LTD.

Maksimenko, S. D. (2006). Genesis of the existence of personality. Kyiv: Publishing house LLC "KMM".

Vizniuk, I. M. (2017). Psychological determinants of the development of hypochondriac disorders of a person by psychodiagnostic parameters. Problems of modern psychology, 35, 55-67.

Ymanets, V. (2016). Distance education as a method of training systems Universities. Warszawa: Wydawca: Sp. z o. o. "Diamond trading tour". одержання випускниками ЗВО знань. Водночас студентів необхідно ознайомлювати з міжнародною рамкою кваліфікацій для сприйняття їхнього саморозвитку.

\section{Висновки}

Таким чином, згідно з поставленою метою, в умовах дистанційного навчання, обгрунтовано особливості психологічної стійкості в студентів та проаналізовано її функції у зв'язку з базовими утвореннями особистості. Констатовано, що успішність у навчанні студентів, як базова категорія дослідження, істотно мало чим відрізняється між КГ і ЕГ тоді, як розлади психосоматичного здоров'я, які спостерігаються в останньої групи осіб, $є$ наслідком розвитку таких особистісних утворень, як схильність до песимізму та низької стресостійкості. Визначено, що між стійкістю тапсихосоматичнимздоров'яміснуєвзаємозв'язок $\left(r_{\mathrm{xy}}=0,359, \mathrm{p} \leq 0,01\right)$, тому іï рівень у студентів $\mathrm{E}^{\mathrm{x}}$ значно нижчий, ніж у КГ осіб, що не впливає на їх успішність в умовах ДН. З'ясовано схожість у показниках успішності між досліджуваними групами, яка свідчить про підвищення можливостей стану оптимального функціонування організму людини в умовах використання IKT.

Показано, що психологічній стійкості людини, іiї урівноваженості та адаптації під час дистанційного навчання, сприяють такі особистісні утворення, як: цілеспрямованість, життєрадісність, енергійність, наполегливість, терпіння, ентузіазм, сміливість, толерантність, безпечність.

\section{Список використаних джерел}

ҮАршава I. Ф. Емоційна стійкість людини та ії діагностика : монографія. Донецьк: ДНУ, 2006. $336 \mathrm{c}$.

Биков В. Ю. Засоби інформаційно-комунікаційних технологій єдиного інформаційного простору системи освіти України: монографія. К.: Педагогічна думка, 2010. С. 98-104.

Кадемія М. Ю. Професійно-технічна освіта в інформаційному суспільстві: монографія. Вінниця: Нілан-ЛТД, 2016. С. 124-45.

Максименко С. Д. Генезис существования личности. К.: 000 “КММ”, 2006. 240 c.

Візнюк I. М. Психологічні детермінанти розвитку іпохондричних розладів у людини за психодіагностичними параметрами. Проблеми сучасної психології. Вип. 35. Кам'янецьПодільський : Аксіома, 2017. С. 55-67.

Ymanets V. Distance education as a method of train- ing systems Universities. Warszawa: Wydawca: Sp.z o.o. "Diamond trading tour", 2016. P. 45-67. 